ARTICLE

Received 19 May 2014 | Accepted 29 Aug 2014 | Published 3 Oct $2014 \quad$ DOl: 10.1038/ncomms6111

\title{
Integrating a redox-coupled dye-sensitized photoelectrode into a lithium-oxygen battery for photoassisted charging
}

Mingzhe Yu', Xiaodi Ren ${ }^{1}, \mathrm{Lu} M \mathrm{M}^{1} \&$ Yiying $\mathrm{Wu}^{1}$

With a high theoretical specific energy, the non-aqueous rechargeable lithium-oxygen battery is a promising next-generation energy storage technique. However, the large charging overpotential remains a challenge due to the difficulty in electrochemically oxidizing the insulating lithium peroxide. Recently, a redox shuttle has been introduced into the electrolyte to chemically oxidize lithium peroxide. Here, we report the use of a triiodide/iodide redox shuttle to couple a built-in dye-sensitized titanium dioxide photoelectrode with the oxygen electrode for the photoassisted charging of a lithium-oxygen battery. On charging under illumination, triiodide ions are generated on the photoelectrode, and subsequently oxidize lithium peroxide. Due to the contribution of the photovoltage, the charging overpotential is greatly reduced. The use of a redox shuttle to couple a photoelectrode and an oxygen electrode offers a unique strategy to address the overpotential issue of non-aqueous lithium-oxygen batteries and also a distinct approach for integrating solar cells and batteries.

\footnotetext{
${ }^{1}$ Department of Chemistry and Biochemistry, The Ohio State University, 100 West 18th Avenue, Columbus, Ohio 43210, USA. Correspondence and requests for materials should be addressed to Y.W. (email: wu@chemistry.ohio-state.edu).
} 
T he lithium-oxygen $\left(\mathrm{Li}-\mathrm{O}_{2}\right)$ batteries are recently attracting increasing research attention because of their higher specific energy density compared with conventional $\mathrm{Li}$ ion batteries ${ }^{1-7}$. In a typical non-aqueous rechargeable $\mathrm{Li}-\mathrm{O}_{2}$ battery, lithium peroxide $\left(\mathrm{Li}_{2} \mathrm{O}_{2}\right)$ is the discharging product formed on the oxygen electrode surface and is oxidized back to $\mathrm{O}_{2}$ and $\mathrm{Li}^{+}$in a following charging process. However, the insulating property of bulk $\mathrm{Li}_{2} \mathrm{O}_{2}$ and the sluggish kinetics of the $\mathrm{Li}_{2} \mathrm{O}_{2}$ oxidation reaction make it difficult to electrochemically decompose $\mathrm{Li}_{2} \mathrm{O}_{2}$ efficiently ${ }^{8}$. This leads to a severe charging overpotential issue, which causes not only a very low battery round-trip efficiency, but also the decompositions of the oxygen electrode and electrolyte ${ }^{3,4,7,9}$. Recently, redox shuttles, such as tetrathiafulvalene (TTF ${ }^{+} / \mathrm{TTF}$ ), have been introduced in the battery electrolyte to address this poor charge transport issue $^{10-14}$. During the charging process, the reduced form of the redox shuttle, $M^{\text {red }}$, is first converted to $M^{\text {ox }}$ on the oxygen electrode, which in turn oxidizes the $\mathrm{Li}_{2} \mathrm{O}_{2}$. By efficiently shuttling charges between $\mathrm{Li}_{2} \mathrm{O}_{2}$ particles and the oxygen electrode surface, it facilitates the oxidation of $\mathrm{Li}_{2} \mathrm{O}_{2}$ and therefore reduces the overpotential ${ }^{13,14}$.

In this work, we introduce the approach of using a redox shuttle to couple a photoelectrode with the oxygen electrode in nonaqueous $\mathrm{Li}-\mathrm{O}_{2}$ batteries, which enables the photoassisted charging process. The photovoltage generated on the photoelectrode compensates the battery's charging voltage. By utilizing solar energy, the device can be charged with a 'negative' overpotential, which is otherwise thermodynamically impossible. This concept of 'photoassisted charging process' offers a novel strategy to address the overpotential issue of non-aqueous $\mathrm{Li}-\mathrm{O}_{2}$ batteries and also a distinct approach for integrating solar cells and batteries ${ }^{15-18}$.

\section{Results}

General design of the solar battery. Figure la shows the structure of the device, named as solar battery, in this work. It consists of three electrodes: a Li-metal anode, an oxygen electrode made from carbon paper and a photoelectrode. The discharging process remains the same as that of a conventional $\mathrm{Li}-\mathrm{O}_{2}$ battery with the formation of $\mathrm{Li}_{2} \mathrm{O}_{2}$ at the oxygen electrode. The charging process is, however, different. The charging voltage is applied on the Limetal anode and the photoelectrode. Under illumination, a photoelectrochemical oxidation occurs on the photoelectrode first, converting $M^{\text {red }}$ into $M^{\text {ox }}$, which in turn diffuses to the oxygen electrode and oxidizes $\mathrm{Li}_{2} \mathrm{O}_{2}$ (Fig. 1b). In this photoassisted charging process, the photovoltage generated on the photoelectrode is utilized to compensate the required charging potential.

In general, either a dye-sensitized photoelectrode or a semiconductor-electrolyte junction can be applied in the solar battery (Fig. 1c and Supplementary Fig. 1) ${ }^{19,20}$. Figure 1c shows the energy diagram of the solar battery based on a dye-sensitized $\mathrm{TiO}_{2}$ photoelectrode ${ }^{20-23}$, as a demonstration of the concept. On charging under illumination, the photoexcited dye molecules inject electrons into the conduction band of $\mathrm{TiO}_{2}$ and are regenerated by oxidizing the $M^{\text {red }}$ to $M^{\text {ox }}$. The formed $M^{\text {ox }}$ species subsequently diffuse to the oxygen electrode, oxidize the solid $\mathrm{Li}_{2} \mathrm{O}_{2}$ to $\mathrm{O}_{2}$ and are reduced back to complete a full redox cycle. The charging voltage equals the energy difference between the redox potential of the $\mathrm{Li}^{+} / \mathrm{Li}$ couple and the quasi-Fermi level of electrons in the $\mathrm{TiO}_{2}$ photoelectrode (which is at best close to the conduction band minimum of $\mathrm{TiO}_{2}, \sim+2.6 \mathrm{~V}$ versus $\mathrm{Li}^{+} / \mathrm{Li}^{22,23}$, all potentials in this manuscript refer to the $\mathrm{Li}^{+} / \mathrm{Li}$ redox) (Fig. 1c). Therefore, we expect that the solar battery has a lower charging voltage than any other conventional non-aqueous $\mathrm{Li}-\mathrm{O}_{2}$ batteries, which have their charging voltage limitation as $2.96 \mathrm{~V}$ (that is, the redox potential of $\mathrm{O}_{2} / \mathrm{Li}_{2} \mathrm{O}_{2}$ ) controlled by thermodynamics. a

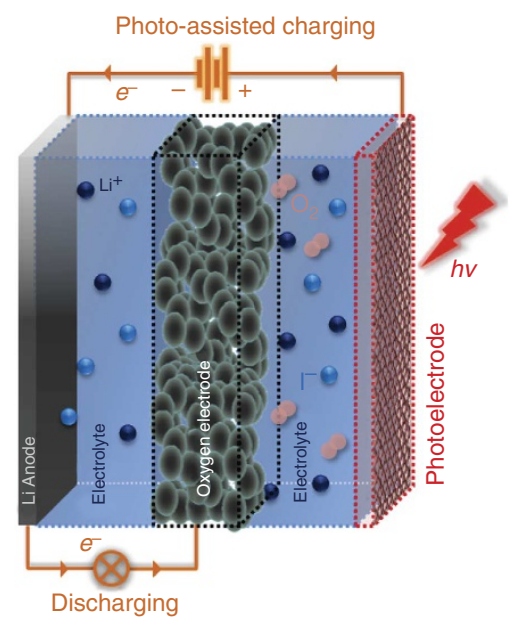

b
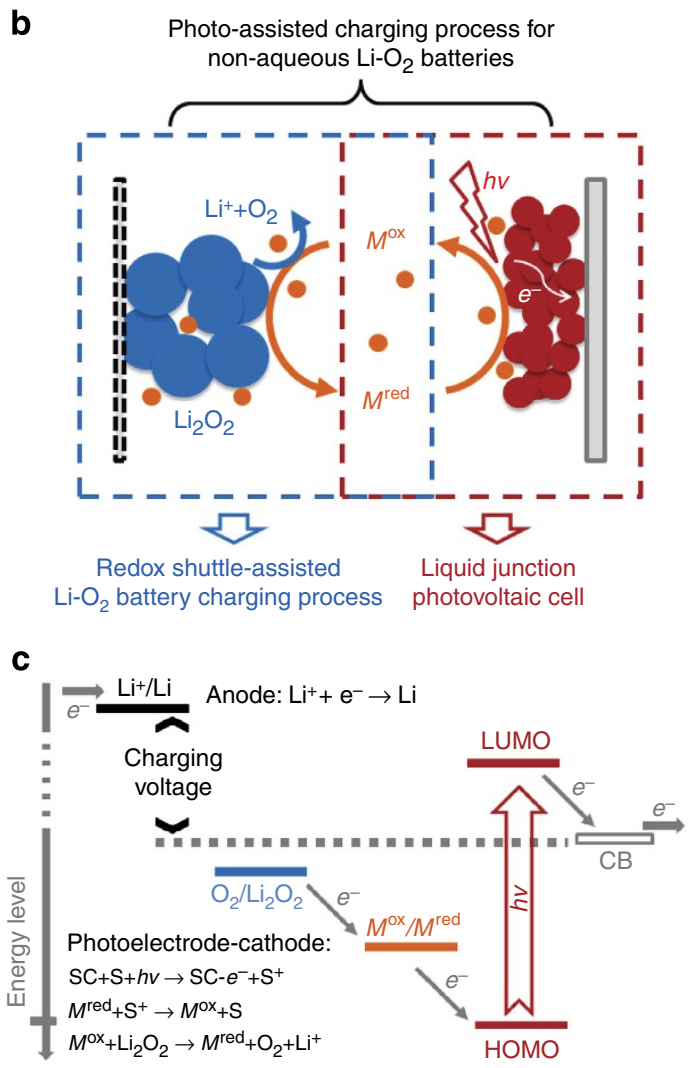

Figure 1 | The photoassisted charging process of the solar battery. (a) The scheme of a three-electrode solar battery: The solar battery consists of a $\mathrm{Li}$ anode, an oxygen electrode and a photoelectrode. On charging, the photoelectrode and $\mathrm{Li}$ anode are connected to the outside circuit; while on discharging, the oxygen electrode and Li anode are connected to the outside circuit. (b) The proposed photoelectrochemical mechanism of the photoassisted charging process: on charging under illumination, the redox shuttle in its reduced form $\left(M^{\text {red }}\right)$ first gets oxidized to $M^{\mathrm{ox}}$ on the photoelectrode and then diffuses to the $\mathrm{Li}_{2} \mathrm{O}_{2}$ particles that are deposited on the oxygen electrode. By oxidizing the $\mathrm{Li}_{2} \mathrm{O}_{2}$ into $\mathrm{O}_{2}$ and $\mathrm{Li}^{+}$, the $\mathrm{M}^{\mathrm{ox}}$ is reduced back to $\mathrm{M}^{\text {red }}$. (c) The energy diagram of a solar battery which integrates a dye-sensitized semiconductor photoelectrode. ('SC' stands for semiconductor and 'S' stands for sensitizer.) The photoassisted charging voltage is determined by the energy difference between the $\mathrm{Li}^{+} / \mathrm{Li}$ redox potential and the quasi-Fermi level of electrons in the semiconductor electrode (at best close to its conduction band (CB) edge.) 
The $\mathrm{I}_{3}^{-} / \mathrm{I}^{-}$redox couple for non-aqueous $\mathrm{Li}-\mathrm{O}_{2}$ batteries. For dye-sensitized $\mathrm{TiO}_{2}$ solar cells, the triiodide/iodide $\left(\mathrm{I}_{3}^{-} / \mathrm{I}^{-}\right)$ redox couple is a benchmark electrolyte for the dye regenera$\operatorname{tion}^{24}$. Despite being mentioned in a patent ${ }^{12}$ and a very recent publication ${ }^{14}$, not much attention has been placed on utilizing $\mathrm{I}_{3}^{-} / \mathrm{I}^{-}$redox couple for non-aqueous $\mathrm{Li}_{-} \mathrm{O}_{2}$ batteries. Therefore, we started with investigating the $\mathrm{I}_{3}^{-} / \mathrm{I}^{-}$couple as a redox shuttle for $\mathrm{Li}-\mathrm{O}_{2}$ batteries. The cyclic voltammetry $(\mathrm{CV})$ reveals that the redox potential of $\mathrm{I}_{3}^{-} / \mathrm{I}^{-}$couple in $1 \mathrm{M} \mathrm{LiClO}_{4} /$ dimethylsulfoxide (DMSO) solution is about $+3.55 \mathrm{~V}$ (Supplementary Fig. 2), consistent with earlier study ${ }^{24}$. Hence, the oxidization of $\mathrm{Li}_{2} \mathrm{O}_{2}$ by $\mathrm{I}_{3}^{-}$is considered to be thermodynamically favourable with a driving force of $0.59 \mathrm{~V}(3.55 \mathrm{~V}-2.96 \mathrm{~V}=0.59 \mathrm{~V})$. Meanwhile, the $\mathrm{CV}$ shape of $\mathrm{I}_{3}^{-} / \mathrm{I}^{-}$redox kept almost identical when the argon atmosphere was replaced by oxygen, indicating its good stability. $\mathrm{Li}-\mathrm{O}_{2}$ batteries were then assembled with surface pretreated $\mathrm{Li}$ metal foil as the anode ${ }^{25}$, commercial P50 carbon paper as the oxygen electrode and a piece of glassy fibre separator ${ }^{9,26,27}$ in between. A solution of $0.1 \mathrm{M} \mathrm{LiI}$ and $1 \mathrm{M} \mathrm{LiClO}_{4}$ in DMSO was used as the electrolyte. (For experimental details, see Methods). The batteries were cycled under one atmosphere of pure $\mathrm{O}_{2}$. A comparison of discharge-charge curves between batteries with and without the redox shuttle is shown in Fig. 2a. At a current flow of $0.16 \mathrm{~mA} \mathrm{~cm}^{-2}$, on charging, the battery with LiI showed a voltage plateau at about $3.5 \mathrm{~V}$, matching well with the $\mathrm{I}_{3}^{-} / \mathrm{I}^{-}$ redox potential. In contrast, the battery without LiI in the electrolyte had its charging voltage quickly climbing up to above $4.0 \mathrm{~V}$. Moreover, batteries with LiI could be charged with a voltage around $3.6 \mathrm{~V}$ even at a current flow as high as $0.47 \mathrm{~mA} \mathrm{~cm}^{-2}$ (Supplementary Fig. 3a). Their cyclability was also evaluated. As shown in Fig. 2b, the batteries could be cycled at $0.16 \mathrm{~mA} \mathrm{~cm}^{-1}$ for at least 25 cycles with only small performance decay. More detailed analysis and discussion of the battery performance are presented in the Supplementary Information (Supplementary Figs 3 and 4).

The dye-sensitized $\mathrm{TiO}_{2}$-based solar battery. With the $\mathrm{I}_{3}^{-} / \mathrm{I}^{-}$ couple demonstrated as an efficient redox shuttle for $\mathrm{Li}-\mathrm{O}_{2}$ batteries, we then consider the structural details of a solar battery. The photoelectrode was a titanium metal gauze decorated with rutilephase $\mathrm{TiO}_{2}$ nanorods (Fig. 3a and Supplementary Fig. 5) and sensitized by the Ruthenizer 535 bis-TBA dye (N719) (ref. 28). The open structure of the wire gauze allows the diffusion of oxygen through the photoelectrode to the oxygen electrode. To test the photochemical activity of this dye-sensitized $\mathrm{TiO}_{2}$ electrode, a solar cell was fabricated. Its photocurrent-voltage curve shows that such a photoelectrode is capable of generating an open-circuit voltage of about $0.73 \mathrm{~V}$ under illumination (Fig. 3b). In such a dye-sensitized $\mathrm{TiO}_{2}$ solar cell, the dye regeneration reaction, which eventually yields $\mathrm{I}_{3}^{-}$from $\mathrm{I}^{-}$, is an 'in situ' process with the time constant on micron-second scale ${ }^{24,29}$. Meanwhile, the robustness of the $\mathrm{I}_{3}^{-}$in oxidizing $\mathrm{Li}_{2} \mathrm{O}_{2}$ has also been demonstrated in the battery tests. Therefore, we consider the $\mathrm{I}_{3}^{-} / \mathrm{I}^{-}$couple as an efficient charge transfer shuttle for transporting electrons between the photoelectrode and oxygen electrode: $2 \mathrm{Dye}^{+}+3 \mathrm{I}^{-} \rightarrow$ $2 \mathrm{Dye}+\mathrm{I}_{3}^{-}$(that is, the dye reduction), $\mathrm{I}_{3}^{-}+\mathrm{Li}_{2} \mathrm{O}_{2} \rightarrow$ $3 \mathrm{I}^{-}+2 \mathrm{Li}^{+}+\mathrm{O}_{2}$ (that is, the $\mathrm{Li}_{2} \mathrm{O}_{2}$ oxidation).

The comparison of charging curves of a simple $\mathrm{Li}-\mathrm{O}_{2}$ battery, a $\mathrm{Li}-\mathrm{O}_{2}$ battery with the $\mathrm{I}_{3}^{-} / \mathrm{I}^{-}$redox shuttle and a solar battery is shown in Fig. 4a,b, at different current densities. Apparently, the addition of $\mathrm{I}_{3}^{-} / \mathrm{I}^{-}$redox shuttle has significantly reduced the charging voltage. It was further reduced with the incorporation of the photoelectrode: the solar battery charging voltage was recorded as 2.72 and $2.83 \mathrm{~V}$ at 0.016 and $0.032 \mathrm{~mA} \mathrm{~cm}^{-2}$, respectively. Considering the small energy difference between the $\mathrm{TiO}_{2}$ conduction band minimum (that is, $\sim+2.6 \mathrm{~V}$ ) and quasiFermi level of electrons in the photoelectrode, we conclude that the results agree well with theoretical predictions. It is also noticeable that the charging voltage is lower than the $\mathrm{O}_{2} / \mathrm{Li}_{2} \mathrm{O}_{2}$ redox potential (that is, $+2.96 \mathrm{~V}$ ), which is thermodynamically impossible without the solar energy input. Once illumination was removed, the voltage increased immediately, indicating the photovoltage no longer existing to compensate the charging voltage of the solar battery. (Supplementary Fig. 6) Such a lightresponse' behaviour further supports our proposed working mechanism for this photoassisted charging process.

To evaluate the coulombic efficiency of this photoassisted charging process, the amount of $\mathrm{Li}_{2} \mathrm{O}_{2}$ on the oxygen electrode before and after the charging process was quantified. It is based on the fast and quantitative reaction: $[\mathrm{TiO}]^{2+} \mathrm{SO}_{4}^{2-}+\mathrm{Li}_{2} \mathrm{O}_{2}+2$ $\mathrm{H}^{+} \rightarrow\left[\mathrm{TiO}_{2}\right]^{2+} \mathrm{SO}_{4}^{2-}+2 \mathrm{Li}^{+}+\mathrm{H}_{2} \mathrm{O}$ (ref. 30). The formed $\left[\mathrm{TiO}_{2}\right] \mathrm{SO}_{4}$ complex has a characteristic absorption peak at $405 \mathrm{~nm}$. Therefore, the amount of $\mathrm{Li}_{2} \mathrm{O}_{2}$ involved in the reaction can be calculated based on the absorbance data. Experimentally, before the photoassisted charging process, $1.76 \mu \mathrm{mol} \mathrm{Li}_{2} \mathrm{O}_{2}$ was deposited on the oxygen electrode by a previous discharging process. After a charging process with $3.60 \mu \mathrm{mol}$ electrons passing through, no detectable $\mathrm{Li}_{2} \mathrm{O}_{2}$ was left (Supplementary Fig. 7). The molar ratio of the oxidized $\mathrm{Li}_{2} \mathrm{O}_{2}$ to the electrons passed through is $1: 2.05$, matching well with the theoretical $1: 2 \mathrm{~mol}$ ratio $\left(\mathrm{Li}_{2} \mathrm{O}_{2}\right.$ : $\left.\mathrm{e}^{-}\right)$. This result, together with the Raman spectra (Supplementary Fig. 8), proves that the $\mathrm{Li}_{2} \mathrm{O}_{2}$ has been efficiently oxidized by the $\mathrm{I}_{3}^{-}$that generated on the photoelectrode.
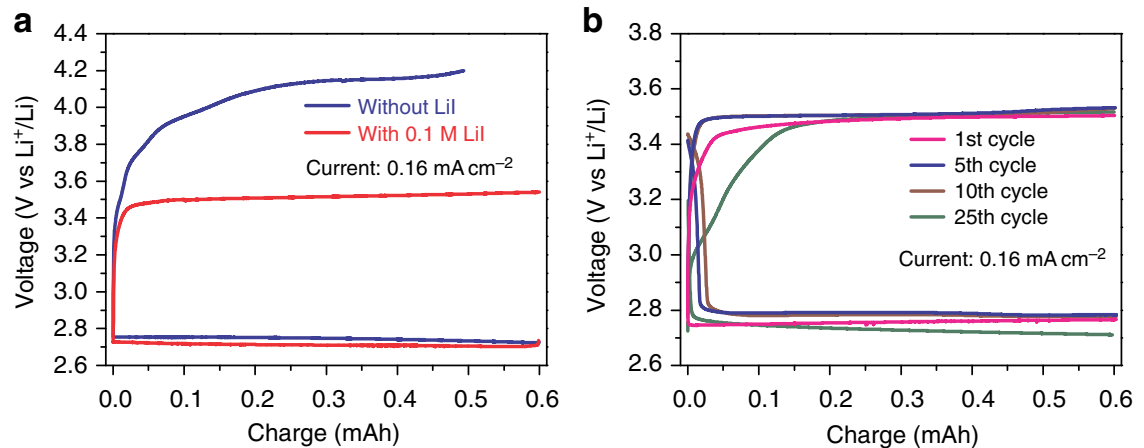

Figure 2 | Electrochemical characterizations of $\mathbf{L i}_{-} \mathbf{O}_{\mathbf{2}}$ batteries with and without the Lil redox shuttle. (a). The first-cycle discharge-charge curve of a $\mathrm{Li}_{-} \mathrm{O}_{2}$ battery with and without Lil redox shuttle at a current density of $0.16 \mathrm{~mA} \mathrm{~cm}^{-2}$. The electrolyte is $1.0 \mathrm{M} \mathrm{LiClO}_{4}$ in DMSO solvent. (b). The dischargecharge curves of a Li- $\mathrm{O}_{2}$ battery with $0.1 \mathrm{M} \mathrm{Lil}$, at the $1 \mathrm{st}$, 5 th, 10 th and 25 th cycle. The current density is $0.16 \mathrm{~mA} \mathrm{~cm}^{-2}$ and the electrolyte is $1.0 \mathrm{M} \mathrm{LiClO}$, $0.1 \mathrm{M}$ Lil in DMSO solvent. The tests are replicated for more than five times. 

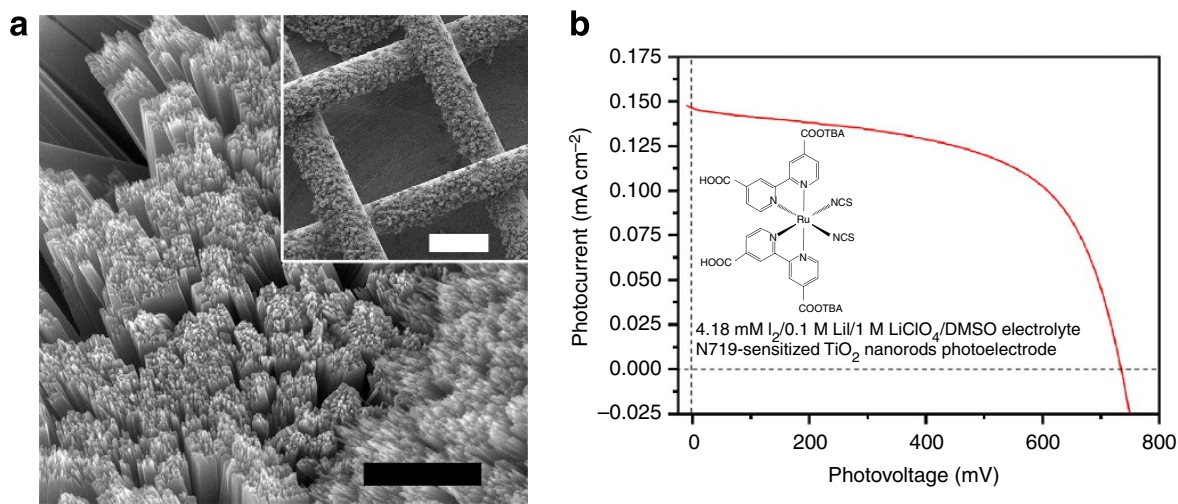

Figure 3 | Characterizations of the dye-sensitized $\mathrm{TiO}_{\mathbf{2}}$ photoelectrode. (a) Representative scanning electron microscopy images for the $\mathrm{TiO}_{2}$ photoelectrode: the rutile-phase $\mathrm{TiO}_{2}$ nanorods were hydrothermally grown on the Ti gauze. (scale bar, $1 \mu \mathrm{m}$; scale bar of the inset image, $100 \mu \mathrm{m}$ ). The open structure of the gauze, shown as the inset, allows the diffusion of oxygen to the oxygen electrode for the $\mathrm{Li}_{2} \mathrm{O}_{2}$ formation; (b). The photocurrentvoltage $(J-V)$ curve of a dye-sensitize solar cell based on this $\mathrm{TiO}_{2}$ photoelectrode, with the inset as the molecular structure of N719 sensitizer. The $J-V$ curve shows that this nanorod $\mathrm{TiO}_{2} @$ Ti gauze photoelectrode could work efficiently by providing an open-circuit voltage $\sim 0.73 \mathrm{~V}$.
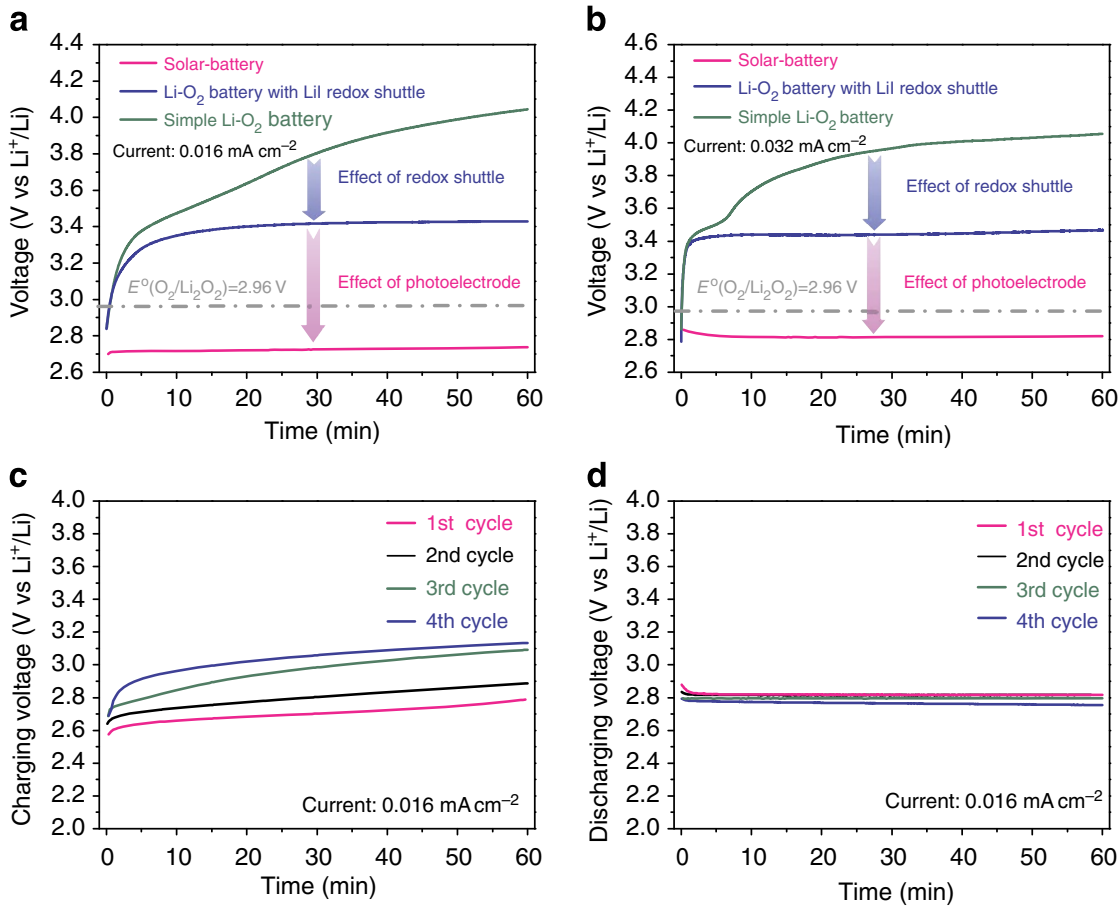

Figure 4 | Electrochemical characterizations of the solar battery. The charging curves of a simple Li- $\mathrm{O}_{2}$ battery, the Li- $\mathrm{O}_{2}$ battery with Lil redox shuttle and the solar battery at a current density of (a) $0.016 \mathrm{~mA} \mathrm{~cm}^{-2}$ and (b) $0.032 \mathrm{~mA} \mathrm{~cm}^{-2}$. The Lil redox shuttle and photoelectrode significantly reduces the battery charging voltage. The solar battery performance of the first four cycles with a current density of $0.016 \mathrm{~mA}^{\mathrm{cm}}{ }^{-2}$ : (c) the charging curves and (d) the discharging curves. The charging curves for the first four cycles show a gradual voltage increasing, which is attributed to the decomposition of the $\mathrm{N} 719$ sensitizer under the strong oxidation environment. The tests are replicated for more than three times.

The solar battery was rechargeable (Fig. 4c,d), however, with a performance decay as cycling went on. By checking the electrodes before and after the solar battery cycling via X-ray photoelectron microscopy (XPS), we attribute this to the gradual decomposition of N719 dye molecules under the strong oxidizing environment (Supplementary Figs 9-11). Hence, improving the stability of photoelectrode is essential. This issue can be solved by replacing the dye-sensitized $\mathrm{TiO}_{2}$ with other more stable photoelectrodes. In fact, our preliminary results of the haematite (that is, $\alpha-\mathrm{Fe}_{2} \mathrm{O}_{3}$ ) photoelectrode based solar battery have shown that a single semiconductor-liquid junction photoelectrode also works efficiently and presents a remarkably better stability. A more detailed discussion of the haematite-based solar battery is presented in the Supplementary Information; (Supplementary Fig. 12). Besides solving the stability issue, the success on haematite-based solar battery further proves that the concept of photoassisted charging process has its generic impact on addressing the charging overpotential issue for $\mathrm{Li}-\mathrm{O}_{2}$ batteries. More work on extending this concept to a large library of photoelectrode materials, such as haematite, doped $\mathrm{TiO}_{2}, \mathrm{BiVO}_{4}$ and so on, is currently undergoing. 


\section{Discussion}

In conclusion, a photoassisted charging process for the nonaqueous $\mathrm{Li}-\mathrm{O}_{2}$ battery has been demonstrated on a solar battery, which integrates a dye-sensitized $\mathrm{TiO}_{2}$ photoelectrode with the oxygen electrode via the linkage of the triiodide/iodide redox shuttle. On charging under illumination, the photoelectrode generates triiodide ions that subsequently diffuse to the oxygen electrode surface and oxidize $\mathrm{Li}_{2} \mathrm{O}_{2}$. The photovoltage generated on the $\mathrm{TiO}_{2}$ photoelectrode compensates the battery's charging voltage. By utilizing solar energy, the device can be charged with a 'negative' overpotential, which is otherwise thermodynamically impossible. The proposed photoassisted charging process has been proved to be efficient. The performance of the solar battery will be further improved by optimizing the device configuration and exploring more stable photoelectrode materials. With this concept demonstrated, our work provides a novel and generic strategy to address issues of low energy efficiency and side reactions brought by the high charging overpotential for nonaqueous $\mathrm{Li}-\mathrm{O}_{2}$ batteries. Furthermore, by using a redox shuttle to couple a photoelectrode and a battery into one device, this work also suggests a distinct approach for integrating solar cells and batteries, which represents an important direction for the future applications in solar energy conversion and storage.

\section{Methods}

Battery and solar battery assembly. All devices were assembled in an argon gasfilled glovebox. For $\mathrm{Li}-\mathrm{O}_{2}$ batteries: the $\mathrm{Li}$ foil $(0.75 \mathrm{~mm}$ thick, $99.9 \%$, Alfa-Aser $)$ was pretreated in $1 \mathrm{M}$ lithium perchlorate $\left(\mathrm{LiClO}_{4}, 99.99 \%\right.$, Sigma-Aldrich) of propylene carbonate (PC, $99.7 \%$, Sigma-Aldrich) solution for three days before used as the anode ${ }^{9}$. A piece of commercial P50 carbon paper $(0.25 \mathrm{~mm}$ thick, $\sim 3.5 \mathrm{mg}, \mathrm{AvCarb})$ and a piece of stainless steel gauze as the current collector (100-mesh, $0.25 \mathrm{~mm}$ thick, Fisher-Scientific) were stacked and used as the oxygen electrode. A piece of glassy fibre $(0.6 \mathrm{~mm}$ thick, Whatman), saturated by the electrolyte as a solution of $0.1 \mathrm{M} \mathrm{LiClO}_{4}$ in DMSO (99.9\%, Sigma-Aldrich), was used as the separator. For the batteries with $\mathrm{I}_{3}^{-} / \mathrm{I}^{-}$redox shuttle, $0.1 \mathrm{M} \mathrm{LiI}(99.9 \%$, Sigma-Aldrich) was added in the electrolyte. The batteries were assembled as Swagelok cells with an O-ring sealing. One atmosphere of high pure $\mathrm{O}_{2}$ was introduced to the oxygen electrode. For solar batteries, the anode and the oxygen electrode were the same as for $\mathrm{Li}-\mathrm{O}_{2}$ batteries. For the photoelectode, $\mathrm{TiO}_{2}$ nanorods were hydrothermally grown on a piece of Ti gauze (80-mesh, FisherScientific) based on a modified recipe ${ }^{31}$. Briefly, the Ti gauze $(\sim 10 \mathrm{mg})$ was first heated at $500{ }^{\circ} \mathrm{C}$ for $30 \mathrm{~min}$ in air to get a dense $\mathrm{TiO}_{2}$ coating layer. Then the gauze was placed in an aqueous solution $(14 \mathrm{ml})$ of $225 \mu \mathrm{l}$ titanium chloride $(99.0 \%$, Sigma-Aldrich) and $0.7 \mathrm{ml} \mathrm{HCl}(\sim 37 \%$, Fisher-Scientific) and hydrothermally heated at $170^{\circ} \mathrm{C}$ for $10 \mathrm{~h}$. After reaction, the $\mathrm{TiO}_{2}$ nanorod-decorated $\mathrm{Ti}$ gauze was washed with water, sintered at $450^{\circ} \mathrm{C}$ for $30 \mathrm{~min}$ and then sensitized with N719 dye molecules (Solaronix). A piece of glassy fibre ( $0.35 \mathrm{~mm}$ thick, VWR) saturated with the $1.0 \mathrm{M} \mathrm{LiClO}_{4} / 0.1 \mathrm{M} \mathrm{LiI} / \mathrm{DMSO}$ electrolyte was used to separate the oxygen electrode and photoelectrode. A fused silica window was O-ring sealed on the cell for allowing the illumination on the photoelectrode. For testing the solar cell, a sandwiched cell was made by a N719-sensitized $\mathrm{TiO}_{2}$ photoelectrode, a platinumcoated fluorine-doped tin oxide glass counter electrode and an electrolyte as $4.18 \mathrm{mM} \mathrm{I}_{2}, 0.1 \mathrm{M} \mathrm{LiI}$ and $1 \mathrm{M} \mathrm{LiClO}_{4}$ in DMSO.

Electrochemical and photoelectrochemical cell testing. $\mathrm{Li}-\mathrm{O}_{2}$ batteries were tested using a Maccor testing station (model: 4304), within a voltage range between 2.0 and $4.2 \mathrm{~V}$ (versus $\mathrm{Li}^{+} / \mathrm{Li}$ ), with discharge and charge current densities varying from 0.016 to $0.79 \mathrm{~mA} \mathrm{~cm}^{-2}$. For solar batteries, the anode and the oxygen electrode were connected to the outside circuit for discharging, while for charging, the anode and the photoelectrode were connected to the outside circuit. A small-area class-B solar simulator (PV Measurements) was used for obtaining a 1.5 Sun AM 1.5 illumination for the solar battery and solar cell tests. CV studies for the $\mathrm{I}_{3}^{-} / \mathrm{I}$ redox couple were carried out on a Gamry potentiostat in a three-electrode con figuration, with a glassy carbon working electrode ( $3 \mathrm{~mm}$ diameter), a platinum wire counter electrode and a $\mathrm{Ag}+/ \mathrm{Ag}$ non-aqueous reference electrode $(10 \mathrm{mM}$ $\mathrm{AgNO}_{3}$ in acetonitrile, from CHI, Inc.). The electrolyte was a solution of $1 \mathrm{M}$ $\mathrm{LiClO}_{4}$ and $5 \mathrm{mM} \mathrm{I}_{2}$ in DMSO. Either argon or oxygen gas was saturated in the electrolyte during the CV tests. The scan rate was $10 \mathrm{mV} \mathrm{s}^{-1}$.

Characterizations. After battery and solar battery tests, the devices were disassembled in the glovebox. The oxygen electrodes were washed with 1,2-dimethoxyethane (Novolyte Tech) and the electrolyte was collected. The Raman spectra of discharged and charged carbon paper oxygen electrodes were collected on a microscope Raman spectrometer (inVia, Renishaw) with a 633-nm excitation wavelength (laser power: $6 \mathrm{~mW}$ ), using an air-sensitive sample holder with a fused silica optical window. The attenuated total reflectance-Fourier transform infrared spectra of discharged and charged carbon paper oxygen electrodes were collected inside a glovebox on a Frontier FT-IR/FIR spectrometer (PerkinElmer) with a diamond window. The XPS analyses of the electrodes were performed on a Kratos Axis Ultra XPS with monochromatic Al X-ray source, at an operation voltage as $12 \mathrm{kV}$ and a current as $10 \mathrm{~mA}$. All the XPS samples were protected from the ambient atmosphere using an air-tight sample transfer module. The scanning electron microscopy (FEI/Philips Sirion Field Emission SEM) was used to obtain the morphology of the $\mathrm{TiO}_{2}$ nanostructure for the photoelectrode and the discharging product on the oxygen electrode. The X-ray diffraction instrument $(\mathrm{Cu}$ $\mathrm{K} \alpha$, Rigaku, Inc.) was used to determine the crystal phase of $\mathrm{TiO}_{2}$ nanorods and the discharging product on the oxygen electrode. For the quantitative analysis of $\mathrm{Li}_{2} \mathrm{O}_{2}$ amount, a calibration curve was first made by reacting different amounts of lithium peroxide with $2 \mathrm{ml} \sim 15 \%$ wt titanium(IV) oxysulfate $\left(\mathrm{TiOSO}_{4}\right) /$ sulfuric acid $\left(\mathrm{H}_{2} \mathrm{SO}_{4}\right.$ ) solution (99.99\%, Sigma-Aldrich) ( $>100$ magnitude excess to the $\mathrm{Li}_{2} \mathrm{O}_{2}$ ) and measuring the absorbance of formed $\left[\mathrm{TiO}_{2}\right]^{2+}$ at $405 \mathrm{~nm}$ with ultravioletvisible (UV-vis) spectra on a Lambda $950 \mathrm{UV} / \mathrm{Vis} / \mathrm{NR}$ spectrometer (PerkinElmer). Then, two parallel solar batteries were assembled and discharged with the same capacity. One was disassembled in the glovebox and the carbon paper oxygen electrode was reacted with $2 \mathrm{ml} \mathrm{TiOSO} / 4 \mathrm{H}_{2} \mathrm{SO}_{4}$ solution. The $\mathrm{Li}_{2} \mathrm{O}_{2}$ amount was determined by UV-vis spectra. The other solar battery was charged under illumination with $3.60 \mu \mathrm{mol}$ electron passing through. After charging, the oxygen electrode was also reacted with $2 \mathrm{ml} \mathrm{TiOSO}{ }_{4} / \mathrm{H}_{2} \mathrm{SO}_{4}$ solution and the $\mathrm{Li}_{2} \mathrm{O}_{2}$ amount left was determined by UV-vis spectra.

\section{References}

1. Abraham, K. M. \& Jiang, Z. A polymer electrolyte-based rechargeable lithium/ oxygen battery. J. Electrochem. Soc. 143, 1-5 (1996).

2. Bruce, P. G., Freunberger, S. A., Hardwick, L. J. \& Tarascon, J.-M. Li-O 2 and Li-S batteries with high energy storage. Nat. Mater. 11, 19-29 (2012).

3. Girishkumar, G., McCloskey, B., Luntz, A. C., Swanson, S. \& Wilcke, W. Lithium-air battery: promise and challenges. J. Phys. Chem. Lett. 1, 2193-2203 (2010).

4. Christensen, J. et al. A critical review of li/air batteries. J. Electrochem. Soc. 159, R1-R30 (2012).

5. Black, R., Adams, B. \& Nazar, L. F. Non-aqueous and hybrid $\mathrm{Li}_{-} \mathrm{O}_{2}$ batteries. Adv. Energ. Mater. 2, 801-815 (2012).

6. Jung, H.-G., Hassoun, J., Park, J.-B., Sun, Y.-K. \& Scrosati, B. An improved high-performance lithium-air battery. Nat. Chem. 4, 579-585 (2012).

7. Lu, J. et al. Aprotic and aqueous Li-O 2 batteries. Chem. Rev. 114, 5611-5640 (2014).

8. Lu, Y.-C. et al. The discharge rate capability of rechargeable $\mathrm{Li}-\mathrm{O}_{2}$ batteries. Energ. Environ. Sci. 4, 2999-3007 (2011).

9. Ottakam Thotiyl, M. M., Freunberger, S. A., Peng, Z. \& Bruce, P. G. The carbon electrode in nonaqueous $\mathrm{Li}_{-} \mathrm{O}_{2}$ cells. J. Am. Chem. Soc. 135, 494-500 (2012).

10. Lacey, M. J., Frith, J. T. \& Owen, J. R. A redox shuttle to facilitate oxygen reduction in the lithium air battery. Electrochem. Commun. 26, 74-76 (2013).

11. Amine, K., Chen, Z. \& Wang, Q. Redox shuttles for overcharge protection of lithium batteries. US Patent 7851092 B2 (2010)

12. Chase, G. V. et al. Soluble oxygen evolving catalysts for rechargeable metal-air batteries. US Patent 20120028137 (2013).

13. Chen, Y., Freunberger, S. A., Peng, Z., Fontaine, O. \& Bruce, P. G. Charging a Li-O $\mathrm{O}_{2}$ battery using a redox mediator. Nat. Chem. 5, 489-494 (2013).

14. Lim, H.-D. et al. Superior Rechargeability and efficiency of lithium-oxygen batteries: hierarchical air electrode architecture combined with a soluble catalyst. Angew. Chem. Int. Ed. 53, 3926-3931 (2014).

15. Little, R. G. Integrated solar cell and battery. U.S. Patent 4740431A (1988).

16. Chen, T. et al. An integrated "energy wire" for both photoelectric conversion and energy storage. Angew. Chem. Int. Ed. 51, 11977-11980 (2012).

17. Guo, W., Xue, X., Wang, S., Lin, C. \& Wang, Z. L. An integrated power pack of dye-sensitized solar cell and $\mathrm{Li}$ battery based on double-sided $\mathrm{TiO}_{2}$ nanotube arrays. Nano Lett. 12, 2520-2523 (2012).

18. Song, T. \& Sun, B. Towards photo-rechargeable textiles integrating power conversion and energy storage functions: can we kill two birds with one stone? ChemSusChem 6, 408-410 (2013).

19. Kamat, P. V., Tvrdy, K., Baker, D. R. \& Radich, J. G. Beyond photovoltaics: semiconductor nanoarchitectures for liquid-junction solar cells. Chem. Rev. 110, 6664-6688 (2010).

20. Grätzel, M. Photoelectrochemical cells. Nature 414, 338-344 (2001).

21. O’Regan, B. \& Grätzel, M. A low-cost, high-efficiency solar cell based on dye-sensitized colloidal $\mathrm{TiO}_{2}$ films. Nature 353, 737-740 (1991).

22. Grätzel, M. Conversion of sunlight to electric power by nanocrystalline dye-sensitized solar cells. J. Photochem. Photobiol. A Chem. 164, 3-14 (2004)

23. Hagfeldt, A., Boschloo, G., Sun, L., Kloo, L. \& Pettersson, H. Dye-sensitized solar cells. Chem. Rev. 110, 6595-6663 (2010). 
24. Boschloo, G. \& Hagfeldt, A. Characteristics of the iodide/triiodide redox mediator in dye-sensitized solar cells. Acc. Chem. Res. 42, 1819-1826 (2009).

25. Peng, Z., Freunberger, S. A., Chen, Y. \& Bruce, P. G. A reversible and higherrate $\mathrm{Li}-\mathrm{O}_{2}$ battery. Science 337, 563-566 (2012)

26. Xu, D., Wang, Z.-1., Xu, J.-j., Zhang, L.-1. \& Zhang, X.-b. Novel DMSO-based electrolyte for high performance rechargeable $\mathrm{Li}_{-} \mathrm{O}_{2}$ batteries. Chem. Commun. 48, 6948-6950 (2012).

27. Trahan, M. J., Mukerjee, S., Plichta, E. J., Hendrickson, M. A. \& Abraham, K. M. Studies of Li-air cells utilizing dimethyl sulfoxide-based electrolyte. J. Electrochem. Soc. 160, A259-A267 (2013).

28. Nazeeruddin, M. K. et al. Conversion of light to electricity by cis-X2bis(2,2'bipyridyl-4,4'-dicarboxylate)ruthenium(II) charge-transfer sensitizers $(\mathrm{X}=\mathrm{Cl}-, \mathrm{Br}-, \mathrm{I}-, \mathrm{CN}-$, and $\mathrm{SCN}-)$ on nanocrystalline titanium dioxide electrodes. J. Am. Chem. Soc. 115, 6382-6390 (1993).

29. Bisquert, J., Zaban, A., Greenshtein, M. \& Mora-Seró, I. Determination of rate constants for charge transfer and the distribution of semiconductor and electrolyte electronic energy levels in dye-sensitized solar cells by open-circuit photovoltage decay method. J. Am. Chem. Soc. 126, 13550-13559 (2004).

30. O'Sullivan, D. W. \& Tyree, M. The kinetics of complex formation between $\mathrm{Ti}(\mathrm{IV})$ and hydrogen peroxide. Int. J. Chem. Kinet. 39, 457-461 (2007).

31. Kumar, A., Madaria, A. R. \& Zhou, C. Growth of aligned single-crystalline rutile $\mathrm{TiO}_{2}$ nanowires on arbitrary substrates and their application in dyesensitized solar cells. J. Phys. Chem. C 114, 7787-7792 (2010).

\section{Acknowledgements}

We acknowledge the funding support from the U.S. Department of Energy (Award no DE-FG02-07ER46427). We acknowledge the generosity of Professor J.E. Goldberger for access to the Fourier transform infrared spectra spectrometer. We thank T.I. Draskovic, Z. Huang, X. Bi, K. Click, J. Xiong and Y. Ju for their valuable comments on the manuscript.

\section{Author contributions}

Y.W. and M.Y. designed this study. M.Y. carried out the experiments. X.R. developed the $\mathrm{Li}-\mathrm{O}_{2}$ battery set-up. L.M. performed the Raman and XPS analyses. All authors contributed to scientific discussions and the writing of the manuscript. Y.W. supervised the research project.

\section{Additional information}

Supplementary Information accompanies this paper at http://www.nature.com/ naturecommunications

Competing financial interests: The authors declare no competing financial interests.

Reprints and permission information is available online at http://npg.nature.com/ reprintsandpermissions/

How to cite this article: Yu, M. et al. Integrating a redox-coupled dye-sensitized photoelectrode into a lithium-oxygen battery for photoassisted charging. Nat. Commun. 5:5111 doi: 10.1038/ncomms6111 (2014). 